\title{
IDEAS OF HABIT AND CUSTOM IN EARLY MODERN PHILOSOPHY JOHN P. WRIGHT
}

There were no single full-length thematic studies of habit during the Early Modern period, though it was discussed in relation to many other topics. Nevertheless, puzzles about habit were posed by many thinkers of this period which were later taken up in the systematic studies of thinkers such as Maine de Biran ${ }^{1}$ and Félix Ravaisson ${ }^{2}$ in the nineteenth century. David Hume wrote of the 'extraordinary' effects of custom or habit - words which Early Modern philosophers used interchangeably. ${ }^{3}$ Joseph Butler noted that 'contrary effects' are 'ascribed to it', and that habit is difficult to distinguish from other mental powers. ${ }^{4}$ Both recognized that through habit some mental phenomena grow stronger, while others grow weaker. Locke argued that through habit an action which is initially painful can become pleasurable; but Hume added that many actions which are pleasurable can become indifferent or even painful through too much exercise. Some philosophers of this period argued that habit destroys voluntary action; but others, going back to Aristotle, argued that actions become voluntary through constant exercise. Some argued that habit could be explained by physical changes in the body, while others rejected anything but a psychological explanation. Habitual behaviour was often characterized as purely mechanical or automatic, performed entirely independently of the mind. But there were other thinkers - particularly physiologists - who argued that while habit causes actions to become unconscious they are still fully under the power of the mind and will. Contrary claims about habit are not only found in different authors, but also in different parts of the works of a single author.

Habit was generally defined both by way of the repetitious actions which produce it, and by the products which result from such repetition - an ability, an inclination, or an urge to act which is more or less resistible. In his Essay Concerning Human Understanding (1690), John Locke defines habit as "the power or ability of man, of doing anything when it has been acquired by frequent doing of the same thing." ${ }^{5} \mathrm{He}$ goes on to distinguish habit as a power or ability from habit as a "disposition" which is "forward and ready on every occasion, to break into action" (ibid). His example of the first is boldness, which is "the power to speak or do what we intend before others without fear or disorder" (ibid). In this description, our intention to be bold is independent of the habit, which gives us the power or ability to realize it. His example of habit as a disposition is "testiness, or an aptness to be angry" (ibid). In this case, he does not mention an intention, and it would seem that the habit can operate independently of the person who possesses it. It can 'break into action' in spite 
of his best intentions. On the one hand, habit is considered merely as an ability to perform an action which arises from repetition of the same action; on the other, it is an actual tendency to act which is difficult to resist.

\section{Reid and Kant on Habit as a Mechanical Principle}

It is this latter meaning of the term habit which was taken up by Thomas Reid in his Essays on the Active Powers of Man (1778). He writes of habits as mechanical principles of action which, like instincts, operate "without will or intention, [and] without thought." They only differ from instincts in their origin — that is, in the fact that they arise from having done a thing frequently. Reid also distinguishes habits considered as mechanical principles of action from 'habits of art' — that is, skills which are simply strengthened and developed by repetition. He suggests that when Aristotle identified virtues as hexeis in Book II of the Nicomachean Ethics, he simply considered them as skills. However, Reid tells his reader that he himself identifies habits as principles of action which are mechanical and without intention or thought. As such, he is particularly concerned with harmful habits which people acquire when children, largely through imitation of those around them. Habits which arise in this way cause one to behave in ways that are, at best, very difficult to correct. They manifest themselves without any act of will; and it takes 'a particular will and effort' to prevent them. Reid writes that "we are carried by habit as by a stream in swimming, if we make no resistance" (ibid).

Like his contemporary, Immanuel Kant, Reid denies that virtues were constituted by habit. He distinguished virtues from corresponding affections which arise from instinct or habit. While "the affection of benevolence is a propensity to do good, from a natural constitution or habit", the "virtue of benevolence' is 'a fixed purpose or resolution to do good from ... duty',"7 Reid stressed that beneficial affections or 'good natural tempers' are not virtues, and that they themselves are "really involuntary, though they often lead to voluntary actions" (ibid). Kant went further when he defined habit as "a physical inner necessitation to continue behaving in the same way we have behaved so far", and argued that as such it "deprives even good actions of their moral value because it detracts from our freedom of mind." For Kant, "as a rule, all habits are objectionable". ${ }^{8}$

\section{Habits as Voluntary Actions}

But the views of Reid and Kant on virtue and habit are not representative of eighteenth-century philosophers. When Joseph Butler discussed 'moral discipline and improvement' in his Analogy of Religion he followed Aristotle's view of habits as constituting virtues. ${ }^{9}$ He elaborates on Aristotle's claims in Book 2 of the Nicomachean Ethics that "moral or ethical virtue is the product of habit (ethos)" and that "our moral dispositions are formed as a result of the 
corresponding activities." ${ }^{10}$ Butler writes that the power of habits is to give us "facility in any kind of action" and to bring about "settled alterations in our temper and character". ${ }^{11}$ Habit for Butler is the source of moral improvement. Habitual actions are voluntary actions.

Locke too argues for the power of habit to change our behaviour and character for the better. Habit has the power of making objects or actions pleasant which were initially unpleasant, and so making them desirable. He states that "the pleasure of the action it self is best acquir'd or increased, by use and practice". ${ }^{12} \mathrm{He}$ holds, for example, that a food which we initially find distasteful, but which we know to be healthy can, by being eaten regularly, become pleasant and desirable. "In Virtue too", an action which is at first difficult, but which we recognize as contributing to our long term happiness can become pleasant "by use and practice" (ibid). "Habits", Locke writes, "have powerful charms, and put strong attractions of easiness and pleasure into what we accustom ourselves to" (ibid). Moreover, we can get rid of the bad habits which we have acquired from fashion, popular opinion, and bad education through "contrary habits" which "change our pleasures, and give relish to that, which is necessary, or conducive to our [long range] happiness" (ibid).

Early modern philosophers recognized the power of habit to improve both our intellectual abilities as well as our moral characters. Habit can be employed in the service of reason and virtue. In his Rules for the Direction of the Mind and Discourse on Method, Descartes stresses the importance of developing correct habits of intuiting simple truths, and reasoning in an orderly way from them. In his Sixth Discourse he writes that "by investigating easy matters first and then moving on gradually to more difficult ones, [people]... will acquire habits more useful" than the rules he has set out. ${ }^{13} \mathrm{He}$ tells his reader that he himself has developed "the habit and facility ... for always finding new truths ..." (ibid). Habit also plays a fundamental role in Descartes' theory of the passions. In order to improve on our natural passionate responses to external objects we need to condition ourselves for better ones. He writes that "although each movement of the [pineal] gland seems to have been joined by nature to each of our thoughts from the beginning of our life, one can nevertheless join them to others by habituation." ${ }^{14}$ For example, "in order to excite boldness and displace fear in oneself, it is not sufficient to have the volition to do so-one must apply oneself to attend reasons, objects, or precedents that convince [one] that the peril is not very great, that there is more security in defence than flight ...." (Art. 45). On Descartes' view it is only through habits which become embedded in the body that we can gain power over our passions.

Like Descartes, Locke holds that we need to develop correct habits of reasoning when we are young. In his Conduct of the Understanding he writes that "it is only practice that improves our minds as well as our bodies, and we must expect nothing of our understandings any further than they are perfected 
by habits." 15 Locke argues that correct habits of reasoning need to be formed in our youth, and recommends training young people in mathematics "as a way to settle in the mind a habit of reasoning closely in train" (ibid). He also stresses the importance of training in probable reasoning "where there wants demonstration to establish the truth beyond doubt" (ibid). Young people need to become "accustomed to" reasoning on both sides of an issue which cannot be decided with absolute certainty in order to "enlarge their minds, and give a due freedom to their understandings" (ibid). Good intellectual habits, far from restricting us, free us to reason properly.

\section{Locke on Involuntary Habits}

On the other hand, there are contexts in which Locke holds that habit makes the operations of our minds insensible and thus involuntary. This is clear from his discussion of visual perception in his Essay Concerning Human Understanding. He writes that "the Ideas we receive by sensation, are often by grown People alter'd by the Judgment, without our taking notice of it". ${ }^{16}$ This occurs as a result of "an habitual custom" which "alters the appearances into their causes" (ibid). Thus we judge that we are seeing a three-dimensional object when all that actually appears to our sense of sight is a two-dimensional surface with varied shadow and colour. Locke's explanation of the fact that we are no longer aware of making a judgment from these visual cues to the shape of the object is that the action of judging has become so quick from habit that we cannot attend to it. He writes that "a settled habit, in things whereof we have frequent experience, is performed so constantly, and so quick, that we take that for the Perception of our sensation, which is an Idea formed by our judgment."17

Locke held that the fact that we are not aware of the judgments we make regarding visual perception is an instance of a more general law of habit. "Habits", he writes, "especially such as are begun very early, come, at last, to produce actions in us, which escape our observation". ${ }^{18}$ Other examples he mentions of habits formed when we were very young, of which we are no longer aware, include the spontaneous closing of our eyelids, and idiosyncratic speech patterns. By habit we have become so used to blinking that we fail to notice "how frequently we ... in a day, cover our Eye-lids, without perceiving that we are at all in the dark" (ibid). Also, "men that by custom have got the use of a By-word, do almost in every sentence, pronounce sounds, which, though taken notice of by others, they themselves neither hear nor observe". ${ }^{19}$

While Locke does not explicitly designate these insensible habitual actions involuntary, it is difficult to see how he could deny that they are. He defines a voluntary action as one performed "consequent to... [an] order or command of the mind" and states that "whatsoever action is performed without such a thought of the mind is called Involuntary". ${ }^{20}$ Since we are neither aware of making perceptual judgments regarding the three-dimensional shapes of the 
objects which appear to sight, nor the spontaneous closing of our eyelids, such actions would seem to be involuntary.

But elsewhere in his Essay Locke does explicitly acknowledge that actions done from habit are involuntary. Consider his discussion of the results of custom and habit in the chapter on association of ideas which he added to the fourth edition of his Essay Concerning Human Understanding in 1700. Here he argued that "Intellectual Habits"21 contracted in childhood often become completely impervious to reason when we are adults. He opened the chapter by noting that while men readily recognize unreasonableness in other people they are usually totally unaware of it in themselves. A man is often "guilty of much greater Unreasonableness in his own Tenets and Conduct" than that which he identifies in others "which he never perceives and will... hardly, if at all be convinced of". ${ }^{22}$ Such unreasonableness is generally the result of indoctrination. Locke writes that unrelated ideas are "by Education, Custom, and the constant din of their Party, so coupled in [men's] Minds, that they can no more separate them in their Thoughts, than if they were but one Idea." ${ }^{23}$ This results in patterns of inference such as that of a man who unreflectively infers from the belief that the leader of his party is a good man to the conclusion that everything he says is true. ${ }^{24}$ Through such inferences, habit leads to the "Irreconcilable opposition between different Sects of .... Religion" and politics, not only because it prevents people from seeking out the evidence for their opinions, but because "it hinders Men from seeing and examining." 25 Locke admits that however much deceived, we do not "impose wilfully" on ourselves "and knowingly refuse Truth offer'd by plain Reason" (ibid). In other words, such irrationality is involuntary.

\section{Mechanical Explanations of Custom and Habit}

In fact, in the chapter on association of ideas Locke appeals to a mechanical cause of habit in order to account for this inability of reason to overcome human irrationality:

Custom settles habits of Thinking in the Understanding, as well as Determining in the Will, and of motions in the Body; all which seems to be but Trains of Motion in the Animal Spirits, which once set a going continue on in the same steps they have been used to, which by often treading are worn into a smooth path, and the Motion in it becomes easy and as it were Natural. ${ }^{26}$

This would explain why habitual actions are often performed absent-mindedly, as when an organist plays a well known tune "though his unattentive Thoughts be elsewhere a wandering" (ibid). Though Locke expresses some doubts about this mechanical explanation of habit, he tells his reader that it may at least help one "to conceive of Intellectual Habits, and the tying together of Ideas" (ibid) which are not joined by reason.

In suggesting such an explanation Locke was drawing on the speculations of Cartesian philosophers. In Book 3 of his Search after Truth (1674), entitled 'Of 
the Imagination', Nicolas Malebranche had argued that habits depended on changes in the brain:

The cause of this connection of many [brain] traces is the identity of the times at which they were imprinted on the brain... It is enough that many traces were produced at the same time for them all to rise together. This is because the animal spirits, finding the path of all the [brain] traces made at the same time half open, continue on them since it is easier for them to travel those paths than through other parts of the brain. This is cause of memory and of the bodily habits we share with the beasts. ${ }^{27}$

Malebranche explains the difficulty we have "moving our fingers with the speed necessary for playing musical instruments, or in moving the muscles used in pronouncing a foreign language" by hypothesizing that these pathways in the brain are not yet formed. ${ }^{28}$ However, "little by little the animal spirits open and smooth out these pathways by their continual flow, so that in time they find no more resistance" (ibid) and bodily habits come to be developed. Malebranche wrote that "it is this facility the animal spirits have of flowing into the members of our bodies that habits consist" (ibid). Moreover, he holds that repetition strengthens the connections between brain traces and their corresponding ideas; "we imagine things more strongly in proportion as these traces are deeper and better engraved, and ... when the spirits have passed through these traces many times, they enter there more easily than other places." 29 Like Locke later, Malebranche appeals to this theory to explain false judgments and false connections of ideas.

\section{Butler on the Double Effect of Habit}

Can the analysis of habits as voluntary actions and involuntary behaviour be reconciled? In his Analogy of Religion of 1737, Joseph Butler seeks to explain the contrary effects of habit through a distinction between what he called passive and active habits - between "habits of perception" and "habits of action". ${ }^{30} \mathrm{He}$ gives as an instance of the first "our constant and even involuntary readiness, in correcting the impressions of our sight concerning magnitudes and distances, so as to substitute judgment in the room of sensation imperceptibly to ourselves" (ibid) — probably having in mind Locke's theory concerning the insensible and involuntary judgments of sight in the Essay, as well as Berkeley's further development of that theory in his New Theory of Vision. ${ }^{31}$ Butler also identifies "our readiness in understanding languages upon sight, or hearing of words" as a passive habit, distinguishing it from the active habit of "our readiness in speaking and writing them" (ibid). What he calls "the exertion of inward practical principles" which he likens to bodily exercise, is also an active habit (ibid, p. 110).

Butler develops this distinction between active and passive habits in a fascinating way in his discussion of the development of moral character. He argues that at the same time as repetition of our moral actions strengthens them, the impressions which originally motivated them "are less and less sensibly 
felt" ${ }^{32}$ For example, the apprehension of danger originally causes the passive impression of fear and the action of defending ourselves. But as a person constantly confronts such situations in practice and becomes habituated to defending himself, he feels less and less fear. In this way, a person becomes courageous. Butler accounts for the development of benevolence as a virtue in a similar way. The perception of others' misery is originally accompanied by pity; but as one frequently assists those in need one "grows less and less sensibly affected with the various miseries of life" (p. 112). As this occurs one acquires the ability to seek out the reasons for a person's destitution and acquires "a greater aptitude actively to assist and befriend them" (ibid). As one becomes a benevolent person the passive impression of pity grows weaker and one's ability to aid those who need one's help grows greater. Butler writes that at the same time as "active Principles" are "wrought ... thoroughly into the Temper and Character" of a person through habit so that they "become more effectual in influencing .... Practice", the original passive feelings had become "less lively in Perception" (ibid).

Butler does not further elaborate on his notion of passive habits, but it is not hard to see how his principle that "passive impressions, by being repeated, grow weaker" might be applied to behaviour caused by imitation or indoctrinationsources of habit stressed by Reid and Locke. We become less and less aware of behaviour caused by these passive impressions as they are constantly repeated, so that in the end they become wholly involuntary and insensible.

\section{Habit and Custom in Hume's Philosophy}

Hume takes up Butler's distinction between the differential effects of habit on actions and impressions in his discussion of the passions in Book 2 of his Treatise of Human Nature (1739), when he attempts to explain "why custom encreases all active habits, but diminishes passive." ${ }^{33}$ His account is formulated in the language of Cartesian psychophysiology, which is found scattered throughout the first two books of the Treatise. ${ }^{34}$ New actions or conceptions presented to the soul provide a resistance to the movement of the animal spirits and cause them to be agitated. This augments whatever emotion is directly produced by the object. However, after the novelty wears off, frequent repetition "produces a facility, which is another very powerful principle of the human mind, and an infallible source of pleasure, where the facility goes not beyond a certain degree." ${ }^{35}$ This pleasure, unlike that of novelty, does not result from the "ferment of the spirits", but from "their orderly motion" (ibid) and the fact that there is no longer any resistance to them. Thus habit can "give us relish in time for what at first was most harsh and disagreeable" (ibid). However, when this facility becomes too great, "the actions of the mind" become "faint and languid", due to the loss of vivacity of the spirits. ${ }^{36}$ The pleasure turns into indifference and even becomes disagreeable. Thus too much sex or partying 
not only become indifferent to us when they are indulged in too frequently, but actually become painful. While Hume seems to believe that habit makes us more proficient in these activities, it ultimately weakens the emotion naturally connected with them.

Hume also applies Butler's principle of the double effect of habit in his account of "calm passions" which are able to overcome violent passions because they have become infixed in our character through custom and habit. He wrote that "when a passion has once become a settled principle of action, and is the predominant inclination of the soul, it commonly produces no sensible agitation." ${ }^{37}$ An avaricious person, for example, shows little emotion as he pursues his daily pursuits of acquiring and hoarding wealth. "As repeated custom and its own force have made everything yield" to such a passion "it directs the actions and conduct without that opposition and emotion, which so naturally attend ever momentary gust of passion" (ibid). Custom gives a person 'strength of mind' to overcome violent passions. Thus the person who has acquired the calm passion of avarice can overcome more violent passions connected with the love of pleasure. Hume also argues that calm passions have been mistaken for reason by Platonic philosophers who hold that virtue consists in the control of desires and passions by reason. What stands in opposition to our violent passions are calm passions which are often formed by habit and custom.

Custom and habit play a crucial role in Hume's moral theory, in his account of how a "judicious [moral] spectator" (ibid) reaches an impartial moral judgment in spite of the fact that our sympathy for family and friends tends to make us partial. In order to explain the correction one must make in arriving at such "steady and general points of view" Hume drew an analogy with the way in visual perception we judge that objects remain the same size in spite of our varying distance from the object. ${ }^{38}$ As we have already seen in Butler, this process was explained through habit, which leads us to insensibly substitute judgment for sensation. Similarly, Hume argues that our habitual social interaction with other moral judges leads us to a common perspective for moral judgment. We judge the moral character of any person from the point of view of those who are directly affected by him or her-rather than from our own limited sympathetic feelings.

Again, in his account of the origin of the artificial virtue of justice, Hume argues that a convention or agreement to refrain from taking the goods of others "arises gradually and acquires force by a slow progression and our repeated experience of the consequences of transgressing it" ${ }^{39}$ It was through "repeated experience' that human beings learned gradually to trust each other and develop an expectation of restraint in one another's conduct. Through this expectation they developed "a general sense of common interest" which induced them "to regulate their conduct by certain rules" (ibid) for the stability of possessions. 
Habit plays a fundamental role in establishing the conventions of property which allow human beings to live together in social groups.

In his Enquiry Concerning the Principles of Morals Hume argues that habit makes us insensible of the basis of our moral judgments. According to his moral theory, we disapprove of violations of the rules of justice - that is, the rules of property-because of their harmful effects on the peace and order of society. However, "we are so accustomed to blame injustice, that we are not, in every instance, conscious of ... the pernicious consequences of it". ${ }^{40}$ This is because "what we have very frequently performed from any motives, we are apt likewise to continue mechanically, without recalling, on every occasion, the reflections which first determined us" (ibid). The result is that we think our disapproval of the violation of the rules of property is based on an original instinct, while it is in fact based on our initial recognition of its harmful social consequences.

It would take me beyond the scope of this paper to discuss in any detail the account of the role of custom and habit in Hume's account of inductive inference, and of the origin of the idea of causal power or necessary connection. ${ }^{41}$ In his Enquiry Concerning Human Understanding he writes that

Custom... is the great guide of life. It is that principle alone, which renders experience useful to us, and makes us expect, for the future, a similar train of events with those which have appeared in the past. Without the influence of custom, we should be entirely ignorant of every matter of fact, beyond what is immediately present to the senses. ${ }^{42}$

He goes on to ascribe to custom all instrumental reasoning, and our ability to use objects and other persons to serve our purposes. Without custom "there would be an end at once of all action, as well as the chief part of speculation" (ibid).

In his account of custom and habit as the cause of our inductive inferences Hume applies claims he made elsewhere about the nature of passive habits. Such inferences frequently occur without any reflection on past experience, which "may operate on our mind in such an insensible manner as never to be taken notice of, and may even in some measure be unknown to us". ${ }^{43}$ The reason is that "custom operates before we have time for reflexion" (ibid). Moreover, inferences from past experience are fundamentally involuntary. Hume wrote that after observing the "frequent repetition" of cause and effect "the mind is determin'd by custom to consider its usual attendant" and it is "this impression... or determination which affords me the idea of necessity." 44 While our inferences from past experience can become voluntary and reflective, the point is that that is not what they are originally. Hume stresses that while scientific reasoning goes beyond everyday reasoning it is still founded on a general habit rooted in experience, which makes us suppose "that the future will resemble the past". ${ }^{45}$ At bottom, the principle which makes us and other animals transfer our past experience to the future is "nothing but a species of instinct or mechanical power, that acts in us unknown to ourselves." ${ }^{\prime 6}$ Like other instincts habit operates on the basis of purely mechanical principles, 
though, unlike them, it requires repeated experience to form the pathways in the brain which make us infer the future from the past.

\section{Habit and the Physiological Unconscious}

Given the agreement among all the philosophers we have considered thus far that passive habits are involuntary and mechanical, it is striking to discover that there were early modern physiologists who argued that all habitual action is voluntary, intentional and performed with thought. In his 'Essay concerning the Motions of our Eyes' published in two parts in 1735-37, William Porterfield argues that the uniform motion of our two eyes in focussing on a single object is a voluntary action which becomes unconscious through habit. He notes that "this uniform Motion by Use and Habit at last becomes so necessary, that the Eyes cannot be moved differently; long Custom rendering many Actions necessary, which were not so essentially, nor from the Beginning". ${ }^{47}$ However, he denies that there is any physical or "intrinsical Necessity" in this motion. Rather, as children we recognize that by focussing our two eyes together we can determine the distance of objects, and so "the Mind has imposed upon itself that Law founded upon the Utility and Advantage that arises from this sort of Motion." "88 Porterfield called this sort of necessity a "moral necessity"49 and insisted that it does not make the actions "mechanical and independent of our Will." ${ }^{50}$ For, he wrote, "the Mind, which at first always acted from a Principle of Interest, comes at length to be determined by Habit and Custom" (ibid). Other motions, which are "no doubt voluntary ... of which we are every bit as little conscious", include tuning of the muscles of the ear and, in many cases, the motions of our eyelids (ibid, p. 213).

Porterfield extends this analysis from the discussion of the effects of custom and habit on our external senses to that of all "the vital and natural Motions" of the body. ${ }^{51} \mathrm{He}$ was aware that "it has been alleged by Locke and others, that all the Thoughts and Operations of the Mind, must necessarily be attended with Consciousness", ${ }^{52}$ but he believes that they had not fully taken into account the effects of habit. When children first learn to walk, "the whole Mind is employed in conducting the Motions necessary for their Progression" ${ }^{53}$ so that if they cease to attend to the activity they will soon fall down. But when these motions come to be performed easily through custom and habit, "they need but little Attention, and allow the Mind to employ its most serious and anxious Thoughts about other Matters" (ibid). By parity of reasoning, when a baby is born, its mind is totally involved "in regulating and governing the internal Motions, which are yet difficult, by reason it has not yet been much accustomed to them". ${ }^{54}$ But when the mind does become accustomed to performing vital actions, such as the beating of the heart and natural actions such as the digestion of food, it is progressively able to attend to 'external Objects'. Thus the baby comes to appear "less and less sleepy and unactive" (ibid). In fact, while it 
continues to perform these actions voluntarily, it is now able through habit to direct its attention away from them and attend to those actions required to survive in the outside world.

This account of the reach of habit in governing all vital bodily processes was first put forward by French comparative anatomist and physiologist Claude Perrault in his Essais de Physique of $1680 .{ }^{55}$ Perrault opposed the Cartesian view that the body is an automaton and that all thought is conscious. While "a machine acts necessarily and follows a certain order" which depends upon the structure of its parts, the motions of an animal exhibit a "prudence and discretion". ${ }^{56}$ An animal, according to Perrault, gives every appearance of being the master of the organs of its body. We need to ascribe both feeling and knowledge to it. Perrault defines an animal as a being "which is capable of exercising the functions of life by a principle which is called a soul." 57

Perrault holds that the soul is spread throughout the body and that it exercises its functions by being directly conjoined with the muscles and organs of the body. ${ }^{58}$ Since it is a knowing being it ought "first and foremost to know" the parts to which it is united..$^{59}$ The obvious problem arises why "the motions which are made within us in the digestion of food and the distribution of nutriment, no less than the contraction and relaxation of muscles appear to be imperceptible" (ibid). He solved this problem by making a distinction between the two kinds of knowledge, that which is "obscure and confused" and that which is "clear, explicit and distinct" (ibid). Those which are performed with the first kind of knowledge are performed without attention or reflection.

Perrault holds that what makes thoughts obscure and confused is habit. When the soul first begins to exercise any action it must attend to it by way of clear and distinct thoughts. However, once it has mastered the action through repetition it can attend to other matters which it requires for its survival. "Habit", he writes, "which has the power to make easy the exercise of all the internal functions" of the body, gives the soul "the freedom to attend to those which are external." ${ }^{\prime \prime} 0$ Through habit we can think of and perform many actions at once. The actions performed by habit are done with a will "that is confused and... which we do not apperceive, but which presides over all the actions, which are of the first necessity (and) which contribute to our conservation". ${ }^{61}$ Perrault writes that the movement of the heart is a "proof of the power of habit"; "although it is performed by voluntary muscles, the long habit which the animal has exercised in performing this movement... makes it form a resolution never to interrupt it." Like the motions of our eyes it is an action "absolutely under the control of our will". ${ }^{62}$

\section{Conclusion}

Perhaps the closest we can get to a systematic theory of habit during the Enlightenment is that put forward by these 'animist' physiologists. While their views were not generally accepted, they were still extensively discussed by 
more mainstream physiologists in the latter half of the 18th century. For example, Hume's friend William Cullen methodically criticized the animist theory in his lectures to Edinburgh medical students in the early 1770s. Cullen rejects the theory of unconscious thoughts and an unconscious will put forward by Porterfield, Perrault and other thinkers who maintained what he called "the Stahlian System". ${ }^{63}$ Following Albrecht von Haller, Cullen criticises the view of the animist writers that as a result of habit the mind can have many unconscious thoughts at any one time. ${ }^{64}$ Nevertheless, Cullen himself stresses the role of habit in describing the influence of the mind on the body, and formulated seven laws by which "the action of the brain is ... determined by and regulated by custom and habit; that is, by laws established by frequent and uniform repetition" ${ }^{65}$ These include each of the following:

I. That custom determines the degree of tension ... necessary to the action of muscular fibres.

2. That custom associates motions with sensations, which are not otherwise their causes; so that the renewal of the sensation, or its idea, renews also the motion. 3. That custom associates different motions, so that they cannot be separately performed, though not originally, nor necessarily, connected. 4 . That custom determines the degree of force and velocity by which motions can be performed. 5. That custom determines the order of succession in associated motions, and the velocity with which they should succeed one another. 6. That custom establishes the periodical return of certain sensations and motions, not originally necessary to the economy. 7. That custom fixes an exact period for the return of certain sensations and motions, which, by the laws of the economy, are disposed to return at certain intervals otherwise undetermined.

Cullen goes on to note that these laws are only "with difficulty avoided", and that they are fundamental principles which determine the action of the brain itself, as well as its operations on the rest of the body.

But the most lasting legacy of the Early Modern period for future studies of habit lay in Butler's distinction between passive and active habits-what later became known as "the double law of habit" ${ }^{66}$ In his lectures, Cullen stated that "philosophers have ascertained to us the effects of Custom: [namely] that it diminishes our passive \& increases our active affections". ${ }^{67}$ He noted that all our passive sensations-including those which make us aware of the mind's own activity—are weakened by custom and habit. Cullen wrote that "actions which at first produced a Sensation of Consciousness, as accompanied with volition, come, by repetition, to be performed without any Sensation". ${ }^{68}$ They become, as we would say today, unconscious. On the other hand, actions of the mind itself, as well as of the body, grow stronger through repetition. Repetition and habit give us a 'facility, pliancy, and suppleness' as well increased strength in the performance of any action. ${ }^{6}$

Central Michigan University

\section{References}

1. Pierre Maine de Biran, The Influence of Habit on the Faculty of Thinking, trans. Margaret D. Boehm (Westport, Conn.: Greenwood Press, 1970). 
2. Félix Ravaisson, Of Habit, translation, introduction and commentary by Claire Carlisle and Mark Sinclair (London: Continuum, 2008).

3. On the 'extraordinary' effects of habit, see David Hume, A Treatise of Human Nature, ed. D.F. Norton and M.J. Norton (Oxford: Clarendon Press, 2007), Book 2, Part 3, Section 5, Paragraph 1; ed. L.A. Selby-Bigge/revised by P.H. Nidditch (Oxford: Clarendon Press, 1978), p. 424. Further references to the Treatise are to $T H N+$ the book, part, section, \& paragraph in the Norton edition; and the page number in the Selby-Bigge/Nidditch edition.

4. Joseph Butler, The Analogy of Religion, Natural and Revealed..., second edition (London, 1736), p. 85.

5. John Locke, An Essay Concerning Human Understanding, ed. P.H. Nidditch (Oxford: Clarendon Press) 19792.22.10; hereafter referred to as 'Essay'. Locke's philosophical definition of habit was pretty standard throughout the $18^{\text {th }}$ century. In the Diderot and d'Alembert Encylopédie 'habit' is defined as 'a propensity acquired by the exercise of the same sentiments or actions.' The first edition of the Encyclopedia Brittanica (1772) defines habit "in philosophy...[as] an aptitude or disposition either of mind or body, acquired by a frequent repetition of the same act".

6. Thomas Reid, Essays on the Active Powers of Man in The Works of Thomas Reid D.D., ed. Sir Wm. Hamilton, $8^{\text {th }}$ edition, 2 vols. (Edinburgh: James Thin, 1895), vol. 2, ., Essay III, Chapter III , pp. 550-1

7. Ibid., Essay II, Chapter III, p. 540. My emphasis.

8. For the last three quotations see: Immanuel Kant, Anthropology from a Pragmatic Point of View, trans. Mary Gregor (The Hague: Martinus Nijhoff, 1974), p. 28. Compare The Metaphysics of Morals, where Kant writes that 'Virtue is not to be defined and valued as a mere aptitude, and... as a long-standing habit of morally good actions acquired by practice...' The Metaphysics of Morals, trans. Mary Gregor (Cambridge: Cambridge University Press, 1996), p. 148.

9. Joseph Butler, The Analogy of Religion Natural and Revealed, in The Works of Joseph Butler, vol. 1, ed. W.E. Gladstone (Oxford: Clarendon, 1896), Part 1, Chapter 5, pp. 105-37.

10. See Aristotle, Nicomachean Ethics, ed. \& trans. H. Rackham (London: Heinemann, 1967), II, pp. $71 \& 75$,

11. Analogy of Religion, p. 108

12. Essay, 2.21.69

13. René Descartes, The Philosophical Writings of Descartes, Vol. 1, trans. John Cottingham, Robert Stoothoff, \& Dugald Murdoch (Cambridge: Cambridge University Press: 1985), p. 148; compare Rule Nine, where he writes that we ought to "acquire the habit of intuiting the truth distinctly and clearly" and "acquire the habit of encompassing in his thought at one time facts which are very simple and few in number..." (Philosophical Writings, vol. 1, pp. 33-34).

14. Rene Descartes, The Passions of the Soul, trans. Stephen H. Voss (Indianapolis: Hackett, 1989), Art. 50, p. 47.; cf. Arts., 44-45 \& 136.

15. John Locke, The Conduct of the Understanding, §6, in The Works of John Locke (London: Clarendon Press, 1823), Vol. 3, §7, pp. 222 -3.

16. Essay 2.9.8. It was this observation which led to the famous problem formulated by William Molyneux, which Locke reported in his Essay-the problem of whether a person born blind who gained his sight when he was an adult would be able, without further experience, to distinguish a cube from a sphere by sight. Both Molyneux and Locke denied that this was possible.

17. Essay 2.9.9. This explanation was developed in a very convincing way in the early nineteenth century by Dugald Stewart. See his Elements of the Human Mind, Part 1, Chapter II, 'Of Attention', in The Collected Works of Dugald Stewart, Vol. 2, ed. William Hamilton (Edinburgh: Thoemmes Continuum, 1854), pp. 120-43.

18. Essay 2.9.10

19. Essay 2.9.10

20. Essay 2.21.5 
21. Essay 2.33 .3 \& 2.33 .17

22. Essay 2.33.1. I say that Locke's concern in chapter 33 is with irrationality; but this is not, strictly speaking, accurate. In Essay 1.33.4 he calls the failure of judgment and inference he is discussing a type of madness, and refers back to an explanation of madness which he had given at Essay 2.11.13. There he argued that madmen reason correctly from false principles and attributes the error to the faculty of imagination or fancy, and not to reason itself.

23. Essay 2.33.18

24. This example is given in The Conduct of the Understanding, p.216; compare Essay 4.20.17

25. Essay 2.33 .18

26. Essay 2.33.6

27. Nicolas Malebranche, Search after Truth, trans. Thomas M. Lennon and Paul J. Olscamp (Cambridge: Cambridge University Press, 1997), p. 106; my emphasis.)

28. Search after Truth, p. 108.

29. Search after Truth, p. 134.

30. Joseph Butler, The Analogy of Religion: Natural and Revealed, in The Works of Joseph Butler, vol. 1, ed. W.E. Gladstone (London: Clarendon, 1898), p. 109.

31. Berkeley argued that we do not immediately see distance or magnitude, but merely correlate visual cues with tactual properties through custom and experience. As children we constantly experienced the visual cues of distance along with certain tactual and kinaesthetic sensations. Berkeley wrote that "because the mind has by constant experience found the different sensations corresponding to the different dispositions of the eyes, to be attended each with a different degree of distance in the object; there has grown an habitual or customary connection between these two sorts of ideas" (George Berkeley, An Essay Towards a New Theory of Vision, in The Works of George Berkeley, Vol. 1, BiblioBazaar, 2008, p. 174). For example, we feel a different sensation as our two eyes focus on nearer or more distant objects and from this different sensation we infer the tactual distance of the object. "The inferences we make from visible to tangible ideas... depend... only on mere custom or habit" (p. 260).

32. Analogy of Religion, p. 111

33. David Hume, A Treatise of Human Nature, ed. D.F. Norton and M.J. Norton (Oxford: Clarendon Press, 2007), 2.3.5.5; ed. L.A. Selby-Bigge/revised by P.H. Nidditch (Oxford: Clarendon Press, 1978), p. 424. Further references to the Treatise are to $T H N$, the book, part, section, and paragraph in the Norton edition; and the page number in the Selby-Bigge/Nidditch edition.

On the evidence that Hume is referring to Butler when he attributes the principle to 'a late eminent philosopher', see my Hume's 'A Treatise of Human Nature: An Introduction (Cambridge: Cambridge University Press, 2009), pp. 229-30

34. See my Hume's 'A Treatise of Human Nature': an Introduction, esp. pp. 51-7.

35. $T H N, 2.3 .5 .3 ; 423$

36. $T H N 2.3 .5 .4 ; 423$

37. $T H N 2.3 .4 .1 ; 418-19$

38. Treatise 3.3.1.16; 582

39. Treatise 3.2.2.10; 490

40. David Hume, An Enquiry Concerning the Principles of Morals: A Critical Edition, ed. Tom L. Beauchamp (Oxford: Clarendon Press, 1998), \$3.47, p. 26

41. See my Hume's 'A Treatise of Human Nature': an Introduction, Chapter 3, esp. pp. 102-6, 110 , and 115-116.

42. Enquiry Concerning Human Understanding, Section 5, Paragraph 6; p. 38

43. THN 1.3.8.13; 103-4

44. Treatise 1.3.14.1: 156.

45. THN 1.3.12.9: 134

46. Enquiry Concerning Human Understanding, §9.6, p. 81; cf. §5.22, p. 45.

47. William Porterfield, 'Essay Concerning the Motions of our Eyes: Part I, Of their External Motions', in Medical Essays and Observations, published by a Society in Edinburgh, vol. 3 (Edinburgh, 1735), p. 154. 
48. Ibid., pp. 255-6

49. William Porterfield, A Treatise on the Eye, The Manner and Phaenomena of Vision, 2 vols. (London, 1759), Vol 2, p. 154.

50. William Porterfield, 'Essay Concerning the Motions of our Eyes: Part II, Of their Internal Motions', in Medical Essays and Observations, published by a Society in Edinburgh, vol. 4 (Edinburgh, 1737), p. 214.

51. Ibid, pp. $216 \mathrm{ff}$.

52. Ibid., p. 216. Locke argued that it is unintelligible to say "that any thing thinks without being conscious of it, or perceiving that it does so" (Essay 1.1.19).

53. "Essay Concerning the Motions of our Eyes: Part II...”, pp. 226-7.

54. Ibid., pp. 225-6.

55. See my article 'Perrault's criticisms of the Cartesian Theory of the Soul', in Descartes' Philosophy of Science, eds. Stephen Gaukroger, John Schuster and John Sutton (London: Routledge Press, 2000), pp. 680-96. Also, François Azouvi 'Entre Descartes et Leibniz: l'animisme dans les Essais de Physique de Claude Perrault", Recherches sur le xviie siècle, vol. 5, 1982, pp. 9-19. For a general view of the intellectual work of Perrault see Antoine Picon, Claude Perrault, 1613-1688 ou La Curiosité d'un Classique (Paris: Cnmhs Caisse Nat.Monum., 1989).

56. Claude Perrault, 'Of the External Senses', in Oeuvres diverses de physique et de mécanique de Mrs. C. \& P. Perrault, 2 vols. (Leyden, 1721), vol. II, pp. 513-15.

57. Claude Perrault, 'De la mecanique des animaux', in Ouevres diverses, vol. II, p. 329.

58. The view that 'the soul is spread throughout the body' is attributed to Perrault by Leibniz in his Paris notebook of late 1775 or early 1776. See Wolfgang Hermann, The Theory of Claude Perrault (London: Zwemmer, 1973), p. 196.

59. Claude Perrault, Oeuvres diverses, vol. II, 518.

60. 'Du toucher', Oeuvres diverses, vol. II, 547.

61. Claude Perrault, 'Du Bruit', Oeuvres diverses vol. I, 278.

62. Ibid., p. 277.

63. These ideas were popularized by Georg Stahl (1660-1734), Professor of Medicine at the University of Halle, particularly in his explanation of disease. Like Perrault, Stahl held that habit causes us to lose consciousness, and that the action of the body in fighting off disease is voluntary and under the control of the will.

64. See William Cullen, Institutions of Medicine: Part I, Physiology (Edinburgh: Edinburgh University Press, 1772), §49, p. 45. In his lecture notes Cullen refers to $\$ 573$ of Haller's First Lines of Physiology. Haller wrote in opposition to the Stahlians that the mind "can entertain only one thought or idea at once; for if it endeavours to see two objects at once ... the mind strays in its reasoning, and makes no right judgment of either object" (op. cit., trans. and printed under the supervision of William Cullen (Edinburgh: Edinburgh University Press, 1786), p. 47).

65. Ibid., $\$ 123$, pp. 95-6.

66. See the Editors' Introduction to Félix Ravaisson, Of Habit, translation, introduction and commentary by Claire Carlisle and Mark Sinclair (London: Continuum, 2008), pp. 8-12.

67. 'Lectures on the Institutions of Medicine by William Cullen, 1770-71', National Library of Scotland, MS 3535, fols. 168-9

68. Institutions of Medicine, $\$ 55$, p. 48

69. NLS MS 3535, fol. 169 